\title{
The Role of Leaf Pigment and Antioxidant Levels in UV-B Resistance of Dark- and Light-green Kentucky Bluegrass Cultivars
}

\author{
Xunzhong Zhang1, E.H. Ervin, and R.E. Schmidt \\ Department of Crop and Soil Environmental Sciences, Virginia Polytechnic Institute and State University, \\ Blacksburg, VA 24061-0404
}

AdDitional INDEX WORDS. catalase, chlorophyll, chlorophyll fluorescence, carotenoids, kentucky bluegrass, lipid peroxidation, photochemical efficiency, Poa pratensis, superoxide dismutase

\begin{abstract}
Ultraviolet-B [UV-B (280-320 nm)] radiation is one of the major factors causing quality decline of transplanted sod. Pigments and antioxidants are associated with plant stress resistance, but their roles in turfgrass tolerance to UV-B damage are not well understood. The objectives of this study were to determine if kentucky bluegrass (Poa pratensis L.) cultivars with darker green genetic leaf color possessed greater pigment and antioxidant defense capacities and if such characteristics were associated with greater resistance to UV-B. Two cultivars, 'Moonlight' (dark green) and 'Limerick' (light green), were selected and subjected to continuous, artificial UV-B radiation $\left(70 \mu \mathrm{mol} \cdot \mathrm{m}^{-2 \cdot} \cdot \mathrm{s}^{-1}\right)$. UV-B irradiation reduced turf quality by $\mathbf{5 8 \%}$ ('Moonlight') and 77\% ('Limerick') relative to day 1 when measured 10 days after initiation of UV-B exposure. Higher canopy photochemical efficiency (PEc) was found in 'Moonlight' relative to 'Limerick' under UV-B stress and during recovery. 'Moonlight' contained greater levels of chlorophyll (1.5 to1.6-fold), carotenoids (1.3-fold), superoxide dismutase [SOD (1.0-fold)] and catalase [CAT (1.5-fold)] than 'Limerick' when measured at 10 days after UV-B initiation. Turfgrass quality and PEc were positively correlated with pigments (chlorophyll and carotenoids) and antioxidant enzymes (SOD and CAT), and negatively correlated with lipid peroxidation. The results suggest that selecting dark-green cultivars with greater pigment content and antioxidant activity may be an effective approach for turfgrass breeders and sod producers to improve tolerance of newly transplanted sod to environments with higher UV-B radiation.
\end{abstract}

Kentucky bluegrass is a cool-season turfgrass species that is widely used for sod production, lawns, and athletic fields in the United States and other temperate parts of the world. In sod production, one of the major limitations is quality decline during transport and transplantation of sod. Previous research showed that UV-B radiation stress is one of the major factors causing sod quality decline during transport and transplantation of sod (Ervin et al., 2004a). High respiration rate of turfgrass tissue and microorganisms in the soil pad result in a rapid increase of temperature inside pallet-stacked sod. Temperature stress can kill or severely impact the physiological integrity of turfgrass tissues (King et al., 1982; Heckman et al., 2001; Zhang et al., 2003). Exposure of the heatstressed sod to high levels of UV-B (280-320 nm) radiation at replanting causes photooxidative stress and further decreases the potential for posttransplant sod survival (Ervin et al., 2004b).

As air pollution and stratospheric ozone depletion continues, UV-B radiation at the earth's surface increases (Barker et al., 1997; Bornman et al., 1997; Mackerness, 2000). A high intensity of UV-B irradiation may damage the photosynthetic system and other metabolic processes of plants (Costa et al., 2002; Teramura and Ziska, 1996). Ultraviolet-B irradiation has been shown to decrease the activity of the photosystem II (PSII) complex with a corresponding decrease in electron transport and ATP synthesis (Noorudeen and Kulandaivelu, 1982), ultimately resulting in oxidative stress (Rao et al., 1996). High UV-B may also affect photosynthesis indirectly by photobleaching and photodegradation of pigments (Strid and Porra, 1992; Takeuchi et al., 1995). As a result, turfgrass quality and photochemical activity are significantly reduced (Schmidt and Zhang, 2001).

Received for publication 9 Mar. 2005. Accepted for publication 16 May 2005. 'Corresponding author: xuzhang@vt.edu
Plants possess various means of tolerating or avoiding UV-B stress (Caldwell et al., 1983). Pigments and antioxidants are important UV-B plant defense mechanisms. Phenolic compounds, particularly flavonoids in the epidermis, absorb UV-B and transmit nondamaging longer wavelengths (Kondo and Kawashima, 2000; Perez-Rodriguez et al., 1998). Antioxidants such as superoxide dismutase and catalase function to scavenge reactive oxygen species (ROS) and protect plants from UV-B-induced oxidative damage (Bornman et al., 1997; Rao et al., 1996; Smirnoff, 1995; Teramura and Ziska, 1996). Some pigments, such as carotenoids and anthocyanin, also function as antioxidants. Carotenoids play important protective roles and functions in light-harvesting processes, quenching of triplet state chlorophyll, and scavenging singlet oxygen and other free radicals. Under high light stress, carotenoids are destroyed at a faster rate than chlorophyll (Pallett and Young, 1993). Chlorophyll destruction may be reduced when triplet state chlorophyll is quenched efficiently by carotenoids.

Various antioxidant metabolites and enzymes could scavenge ROS such as superoxide radicals $\left(\mathrm{O}_{2}^{-}\right)$, hydrogen peroxide $\left(\mathrm{H}_{2} \mathrm{O}_{2}\right)$, and hydroxyl radicals $\left(\mathrm{HO}^{*}\right)$ and reduce ROS toxicity to plant cells under UV-B stress. Superoxide dismutases (SOD) are metalloenzymes that convert $\mathrm{O}_{2} \cdot{ }^{\cdot}$ to $\mathrm{H}_{2} \mathrm{O}_{2}$, and are considered as the "primary defense" against ROS (Perl-Treves and Perl, 2002). Hydrogen peroxide is further reduced to water by ascorbate peroxidase (APX). Catalase, localized in peroxisomes, scavenges $\mathrm{H}_{2} \mathrm{O}_{2}$ produced by glycolate oxidase in the $\mathrm{C}_{2}$ photorespiratory cycle (Perl-Treves and Perl, 2002). Antioxidant defense systems are essential for plants to survive stressful environments.

Studies of UV-B irradiation effects on plants have shown a wide range of responses. Some species are particularly sensitive and show signs of damage at moderate increases in UV-B, while other species show no response (Tevini and Teramura, 1989). These differences are also found between cultivars of the same species (Teramura et 
al., 1990). Differences in stress tolerance between closely related plant species or cultivars may be related to differences in the levels of antioxidants and pigments (Bowler et al., 1992). There are currently more than $200 P$. pratensis cultivars with different genetic leaf colors, ranging from dark green (such as 'Moonlight') to light green (such as 'Limerick'). A previous study indicated that UV-B resistance of $P$. pratensis may be associated with pigment content (Ervin et al., 2004b). However, no information is available concerning the variations in UV-B resistance of dark-green and light-green cultivars of kentucky bluegrass and its relation to both leaf pigment concentration and antioxidant activity. Investigations concerning the physiological basis of potential cultivar differences in UV-B stress resistance would provide valuable selection information for turfgrass breeders and sod producers. The objectives of this study were to determine if kentucky bluegrass cultivars with darker green leaf color possessed greater pigment and antioxidant defense capacities and if such characteristics were associated with greater resistance to UV-B.

\section{Materials and Methods}

TURfGrass Culture AND UV-B TreatMent. Kentucky bluegrass cultivars Moonlight (dark-green leaf color) and Limerick (lightgreen leaf color) from the 2000 National Turfgrass Evaluation Program (NTEP) trial, grown on a Groseclose silt loam soil (a clayey, Kaolinitic, mesic Typic Hapludult; pH 6.0, OM 2.2\%) at the Virginia Tech Turfgrass Research Center, Blacksburg, were used for this study. The NTEP trial was established in Oct. 2000 and nitrogen was applied at $49 \mathrm{~kg} \cdot \mathrm{ha}^{-1}$ in May and $85 \mathrm{~kg} \cdot \mathrm{ha}^{-1}$ in November each year. The nitrogen source for all applications was a $31 \mathrm{~N}-0 \mathrm{P}-0 \mathrm{~K}$ with $28 \%$ IBDU and $3 \%$ urea. The field plots were mowed bi-weekly at $3.8 \mathrm{~cm}$ and irrigation was applied at $\approx 2.5$ $\mathrm{cm} /$ week to prevent moisture stress.

Four plugs $(10-\mathrm{cm}$ diameter $\times 5$-cm deep) of each cultivar were taken from the NTEP field plots on 27 Feb. 2003 and placed in PVC rings. The PVC rings were $5 \mathrm{~cm}$ high and the bottom was sealed with plastic film. Three holes were made in the plastic bottom to allow proper drainage. The turfgrass plugs in the rings were placed in a tray $(60 \times 100 \times 6 \mathrm{~cm})$ and placed under a mist system in the greenhouse. Nitrogen was applied at $45 \mathrm{~kg} \cdot \mathrm{ha}^{-1}$ with a $20 \mathrm{~N}-8.8 \mathrm{P}-16.6 \mathrm{~K}$ soluble fertilizer $2 \mathrm{~d}$ after the plugs were transplanted. The cultivar transplants were grown for 3 weeks before initiation of UV-B treatments.

For the UV-B stress treatment, the cultivars were placed under artificial UV-B $\left(70 \mu \mathrm{mol} \cdot \mathrm{m}^{-2} \cdot \mathrm{s}^{-1}\right)$ provided by three $40-\mathrm{W} \mathrm{UV}-\mathrm{B}$ fluorescent lamps (UVB-313; Q-Panel Lab Products, Cleveland, Ohio). The containers were spaced evenly $(2.5 \mathrm{~cm})$, kept $0.5 \mathrm{~m}$ below the UV-B source, and grown under continuous UV-B irradiation in a greenhouse maintained at $20 \pm 2{ }^{\circ} \mathrm{C}$. Daylength averaged $11 \mathrm{~h}$. Plugs were subjected to UV-B from 20 Mar. to 30 Mar. 2003 and irrigated three times per week to prevent moisture stress. Total UV flux (250 to $400 \mathrm{~nm}$ ) from the fluorescent lamps was measured with a UV meter (Apogee Instruments, Logan, Utah). The meter was placed vertically with the sensor $0.5 \mathrm{~m}$ below the UV-B source. On 31 Mar., the plugs were removed from UV-B treatment and placed under a mist system for recovery from 31 Mar. to 14 Apr. Turfgrass quality rating and chlorophyll fluorescence readings took place on days $1,5,10$, and 25 after UV-B initiation. On the same days, leaf samples were collected for analysis of pigments, antioxidant enzymes, and lipid peroxidation. The samples were immediately frozen with liquid $\mathrm{N}$, and stored at $-80^{\circ} \mathrm{C}$ until laboratory analysis could be performed.
TURfGrass QUALITY RATING. Turfgrass quality or injury was rated based on a visual scale of 1 to 9 with 9 indicating the best quality or no injury, and 1 indicating the worst quality or most injury (bleaching).

Canopy photochemical efFiciency (PEC) measurement. The PEc was measured indirectly by chlorophyll fluorescence using a dual wavelength fluorometer (OS-50; Opti-Sciences, Tyngsboro, Mass.). Photochemical efficiency $\left(\mathrm{F}_{\mathrm{v}} 690 \mathrm{~nm} / \mathrm{F}_{\mathrm{m}} 690 \mathrm{~nm}\right.$; that is, a ratio of variable fluorescence to maximum fluorescence at 690 $\mathrm{nm}$ ) was determined from chlorophyll fluorescence signals (Zhang and Schmidt, 2000).

Chlorophyll AND CARotenoids. Chlorophyll a, b, chlorophyll $\mathrm{a}+\mathrm{b}$, and carotenoids were analyzed according to the procedures of Lichtenthaler(1987). Briefly, leaf samples (50 mg fresh weight) were ground with a pestle in $10 \mathrm{~mL}$ of $100 \%$ acetone. The homogenate was centrifuged at $2700 g_{\mathrm{n}}$ for $10 \mathrm{~min}$. The supernatant absorbance at $661.6,644.8$, and $470 \mathrm{~nm}$ was measured using a spectrophotometer (BioMate 3; ThermoSpectronic, Rochester, N.Y.). Concentration of chlorophyll and carotenoids were calculated by the equations of Lichtenthaler (1987) as follows:

$$
\begin{aligned}
& \mathrm{Chl} \mathrm{a}=(11.24 \times \text { absorbance at } 661.6 \mathrm{~nm}) \\
& -(2.04 \times \text { absorbance at } 644.8 \mathrm{~nm}) \\
& \mathrm{Chl} \mathrm{b}=(20.13 \times \text { absorbance at } 644.8 \mathrm{~nm}) \\
& -(4.19 \times \text { absorbance at } 661.6 \mathrm{~nm}) \\
& \mathrm{Chl} \mathrm{a}+\mathrm{b}=(7.05 \times \text { absorbance at } 661.6 \mathrm{~nm}) \\
& +(18.09 \times \text { absorbance at } 644.8 \mathrm{~nm}) \\
& \text { Carotenoids (xanthophylls and } \beta \text {-carotene) } \\
& =(1000 \times \text { absorbance at } 470 \mathrm{~nm}) \\
& -(1.90 \times \text { Chl a }-63.14 \times \text { Chl b }) \div 214
\end{aligned}
$$

Anthocyanin. Anthocyanin content was determined following the procedure of Rabino and Mancinelli (1986). Briefly, anthocyanin was extracted from leaf samples (100 mg fresh weight) by periodically shaking samples over a 48 -h period at 4 ${ }^{\circ} \mathrm{C}$ in acidic (1\% HCL) methanol. The absorbance of the extract, clarified by filtration, was measured at 530 and $657 \mathrm{~nm}$ using a spectrophotometer (BioMate 3$)$. The formula $A_{530}-\left(0.25 \times A_{657}\right)$ was used to estimate anthocyanin content.

Antioxidant ENZYME EXTRACTION. Frozen leaf samples (0.25 g) were crushed with liquid nitrogen and extracted with a pestle in an ice-cold mortar with $4 \mathrm{~mL}$ of $0.05 \mathrm{M} \mathrm{Na}_{2} \mathrm{HPO}_{4} / \mathrm{NaH}_{2} \mathrm{PO}_{4}(\mathrm{pH}$ 7.0) buffer containing $0.2 \mathrm{~mm}$ ethylenediamine-tetracetic acid (EDTA), and 1\% polyvinyl-pyrrolidone (PVP). The homogenates were centrifuged at $4{ }^{\circ} \mathrm{C}$ for $20 \mathrm{~min}$ at $13,000 \mathrm{~g}_{\mathrm{n}}$. The supernatants were collected and used for assays of enzymatic activities.

SuPEROXIDE DISMUTASE (SOD). Superoxide dismutase activity was determined according to the method of Giannopolitis and Ries (1977). The 3-mL reaction mixture contained $63 \mu \mathrm{M}$ nitro blue tetrazolium (NBT), $1.3 \mu \mathrm{M}$ riboflavin, $13 \mathrm{~mm}$ methionine, $0.1 \mathrm{~mm}$ EDTA, $50 \mathrm{~mm}$ potassium phosphate buffer ( $\mathrm{pH} 7.8$ ), and $30 \mu \mathrm{L}$ enzyme extract. The riboflavin was added last. Test tubes containing the mixture were placed under one circular fluorescent lamp (irradiance $\left.=60 \mu \mathrm{mol} \cdot \mathrm{m}^{-2} \cdot \mathrm{s}^{-1}\right)$ at room temperature $\left(25^{\circ} \mathrm{C}\right)$. The reaction was initiated by switching on the light and slowly rotating sample tubes under the light for $10 \mathrm{~min}$. Absorbance at $560 \mathrm{~nm}$ was measured with a spectrophotometer (Biomate 3). A nonirradiated mixture without enzyme extract served as a blank and an irradiated mixture without enzyme extract served as a control. One unit of SOD activity was defined as the amount of enzyme required to cause $50 \%$ inhibition of the rate of NBT reduction.

Catalase (CAT). The CAT activity was determined by the method of Chance and Maehly (1955). The decomposition of $\mathrm{H}_{2} \mathrm{O}_{2}$ 
was measured by following the decline in absorbance at $240 \mathrm{~nm}$ for $2 \mathrm{~min}$. The $3-\mathrm{mL}$ reaction mixture contained $50 \mathrm{~mm}$ phosphate buffer (pH 7.0), $15 \mathrm{~mm} \mathrm{H}_{2} \mathrm{O}_{2}$, and $0.1 \mathrm{~mL}$ enzyme extract. The reaction was started with the addition of the enzyme extract. Absorbance at $240 \mathrm{~nm}$ was read every $20 \mathrm{~s}$. One unit of catalase activity was defined as a change of 0.01 absorbance $/ \mathrm{min}$.

Ascorbate PEROXIDASE (APX). The APX activity was determined according to Nakano and Asada (1981) by monitoring the rate of ascorbate oxidation at $290 \mathrm{~nm}$ (extinction coefficient $=$ $\left.2.8 \mathrm{~mm}^{-1} \cdot \mathrm{cm}^{-1}\right)$. The $1.5 \mathrm{~mL}$ reaction mixture contained $50 \mathrm{~mm}$ potassium phosphate buffer ( $\mathrm{pH} 7.0), 0.1 \mathrm{~mm}$ EDTA, $0.5 \mathrm{~mm}$ ascorbate, $0.3 \mathrm{mM} \mathrm{H}_{2} \mathrm{O}_{2}$, and $30 \mu \mathrm{L}$ enzyme extract. One unit of APX was defined as a change of 0.1 absorbance/min, and activity of APX was expressed as unit per milligram protein.

Peroxidase (POD). The POD activity was determined by monitoring the increase in absorbance at $470 \mathrm{~nm}$ (extinction coefficient $=26.6 \mathrm{mM}^{-1} \cdot \mathrm{cm}^{-1}$ ) due to the oxidation of guaiacol for $2 \mathrm{~min}$ (Chance and Maehly, 1955). The 1.5-mL mixture contained $1.42 \mathrm{~mL} 10 \mathrm{~mm}$ phosphate buffer (pH 7.0), $25 \mu \mathrm{L} 20$ mu guaiacol, and $50 \mu \mathrm{L}$ enzyme extract. One unit of peroxidase was defined as a change of 0.01 absorbance $/ \mathrm{min}$, and activity of POD was expressed as unit per milligram protein.

LIPID PEROXIDATION. The lipid peroxidation in the leaf samples was measured in terms of malondialdehyde (MDA) content. The MDA content was determined according to Heath and Packer (1968). Fresh sample $(0.1 \mathrm{~g})$ was homogenized in $5 \mathrm{~mL} 0.25 \%$ 2-thiobarbituric acid (TBA) in $10 \%$ thiobarbituric acid (TCA) using mortar and pestle. The homogenate was heated at $95^{\circ} \mathrm{C}$ for $30 \mathrm{~min}$ and the mixture was quickly cooled down in an ice bath, and then centrifuged at $10000 \mathrm{~g}_{\mathrm{n}}$ for $10 \mathrm{~min}$. The absorbance of the supernatants was measured at 532 and $600 \mathrm{~nm}$. The value for the non-specific absorbance at $600 \mathrm{~nm}$ was subtracted from the readings at $532 \mathrm{~nm}$. The blank was $0.25 \%$ TBA in $10 \%$ TCA. The concentration of the MDA was calculated using MDA's extinction coefficient of $155 \mathrm{mM}^{-1} \cdot \mathrm{cm}^{-1}$ and expressed as nanomoles per gram fresh weight.

Determination OF PROTEIN CONCENTRATION. Since the activities of antioxidant enzymes are presented on a protein basis, protein concentration for each sample was analyzed by the bicinchoninic (BCA) method, with bovine serum albumin serving as the standard (Smith, 1985).

EXPERIMENTAL DESIGN AND DATA ANALYSIS. A randomized complete-block design was used with four replications. The data were analyzed using analysis of variance and mean separations were performed using a Fisher's protected least significant difference test. Spearman correlation coefficients $(r)$ of turfgrass quality or PEc with various pigments, antioxidant enzymes, and lipid peroxidation were determined, based on data of the two cultivars from day 1 though day 25 for each individual parameter, except for superoxide dismutase activity, which was based on the data from day 5 and day 10 (SAS, 2001).

\section{Results}

TuRfGrass QUALITY. UV-B radiation caused severe turfgrass damage (Fig. 1.). Visual quality measured at day 10 was reduced by $58 \%$ ('Moonlight') and $77 \%$ ('Limerick') compared to that at trial initiation. At day 25, quality was $78 \%$ ('Moonlight') and $65 \%$ ('Limerick') of the original level.

Canopy photochemical EFFiCiency (PEC). Canopy photochemical efficiency declined sharply in the first $5 \mathrm{~d}$ of UV-B exposure and thereafter remained at similar levels (Fig. 2). When

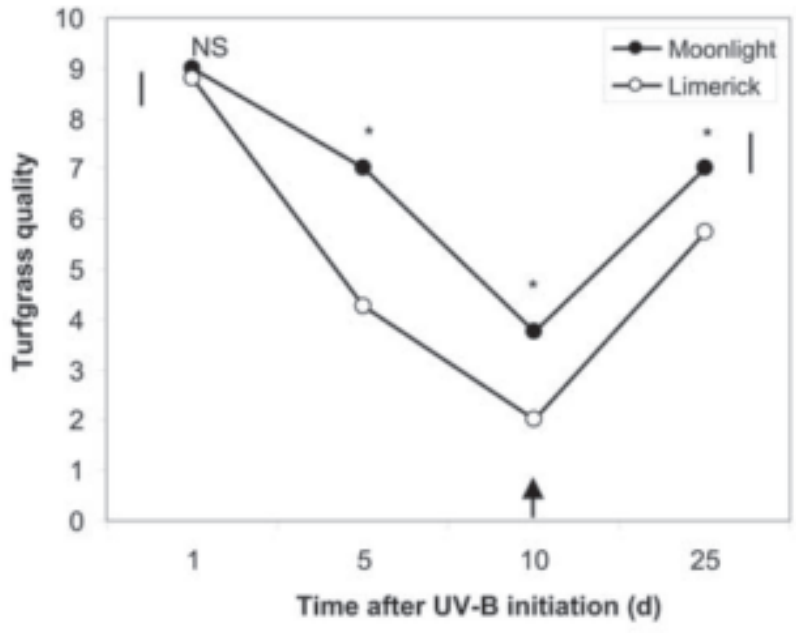

Fig. 1. Turfgrass quality responses to artificial UV-B radiation stress $\left(70 \mu \mathrm{mol} \cdot \mathrm{m}^{-2} \cdot \mathrm{s}^{-1}\right)$ in two kentucky bluegrass cultivars. Turfgrass quality was rated on 1 to 9 visual scale with 9 indicating the best quality. The difference between the two cultivars was significant at $P=0.05(*)$ or nonsignificant (NS) at a given day. The arrow indicates time of UV-B removal. Vertical bars represent LSD values $(P=0.05)$ values for 'Moonlight' (left) and 'Limerick' (right) over time of treatment.

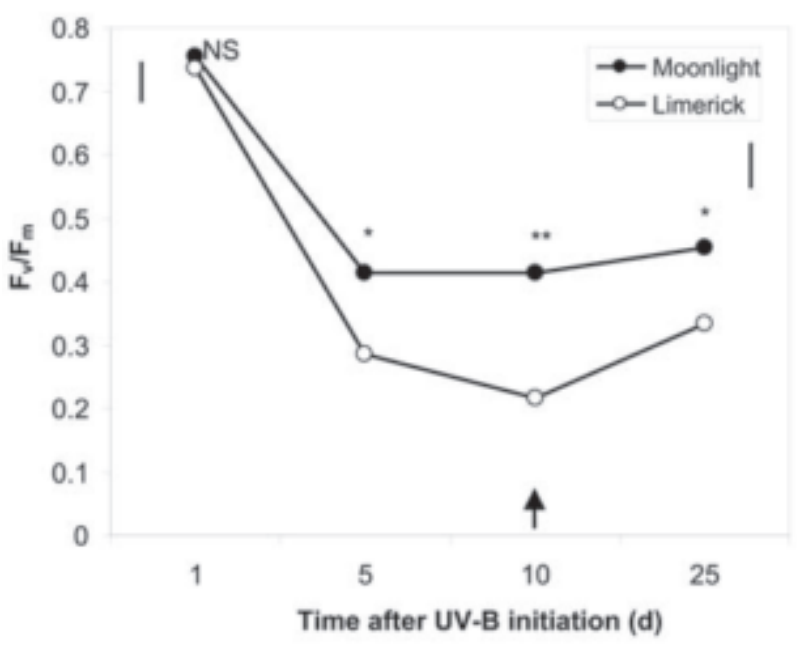

Fig. 2. Canopy photochemical efficiency $\left(\mathrm{PEc} ; \mathrm{F}_{\mathrm{v}} / \mathrm{F}_{\mathrm{m}}\right)$ responses to artificial UV$\mathrm{B}$ radiation stress $\left(70 \mu \mathrm{mol} \cdot \mathrm{m}^{-2} \cdot \mathrm{s}^{-1}\right)$ in two kentucky bluegrass cultivars. The difference between the two cultivars was significant at $P=0.05$ (*) $^{*} P=0.01$ (**), $^{*}$, or nonsignificant (NS) at a given day. The arrow indicates time of UV-B removal. Vertical bars represent LSD values $(P=0.05)$ values for 'Moonlight' (left) and 'Limerick' (right) over time of treatment.

measured at 10 d after UV-B initiation, PEc was 55\% ('Moonlight') and $29 \%$ ('Limerick') of the original level. At day 25, PEc was $60 \%$ ('Moonlight') and 45\% ('Limerick') of the PEc at day 1.

Chlorophyll content. Chlorophyll a, b, and $\mathrm{a}+\mathrm{b}$ showed a similar response to UV-B stress; therefore, only chlorophyll $\mathrm{a}+\mathrm{b}$ content was presented (Fig. 3). Chlorophyll $\mathrm{a}+\mathrm{b}$ content declined rapidly in the first $5 \mathrm{~d}$ of UV-B exposure and then changed slightly during the final $5 \mathrm{~d}$ of UV-B stress. When measured at day 10 , chlorophyll $\mathrm{a}+\mathrm{b}$ content was reduced by $60 \%$ ('Moonlight') and $81 \%$ ('Limerick') compared to that at day 1. At day 25, chlorophyll a+b content was $72 \%$ for 'Moonlight' and $60 \%$ for 'Limerick' relative to the original level (day 1).

Carotenoids Content. UV-B stress caused a reduction of carotenoids, particularly in the first $5 \mathrm{~d}$ (Fig. 4). At $10 \mathrm{~d}$ after UV-B 


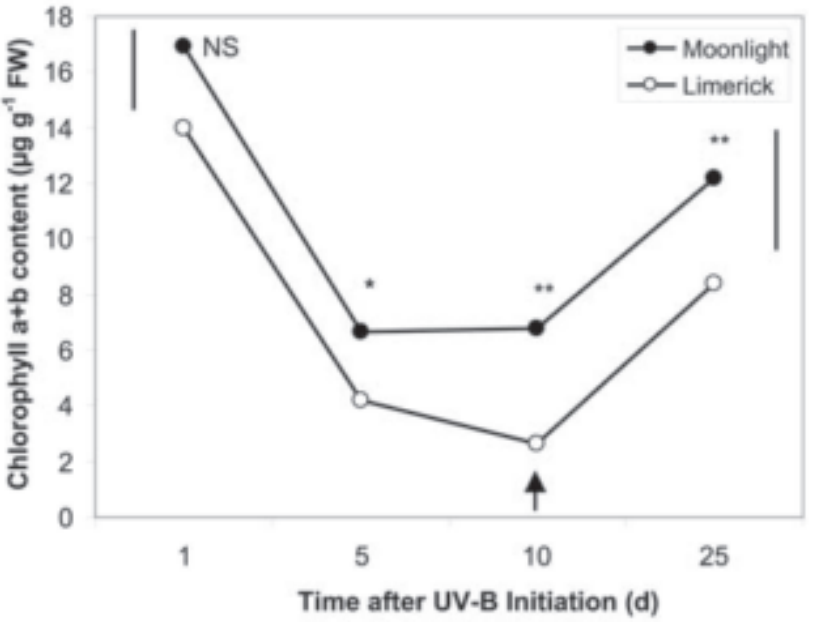

Fig. 3. Chlorophyll a+b content responses to artificial UV-B radiation stress (70 $\left.\mu \mathrm{mol} \cdot \mathrm{m}^{-2} \cdot \mathrm{s}^{-1}\right)$ in two kentucky bluegrass cultivars. The difference between the two cultivars was significant at $P=0.05(*), P=0.01$ (**), or nonsignificant (NS) at a given day. The arrow indicates time of UV-B removal. Vertical bars represent LSD values $(P=0.05)$ values for 'Moonlight' (left) and 'Limerick' (right) over time of treatment.

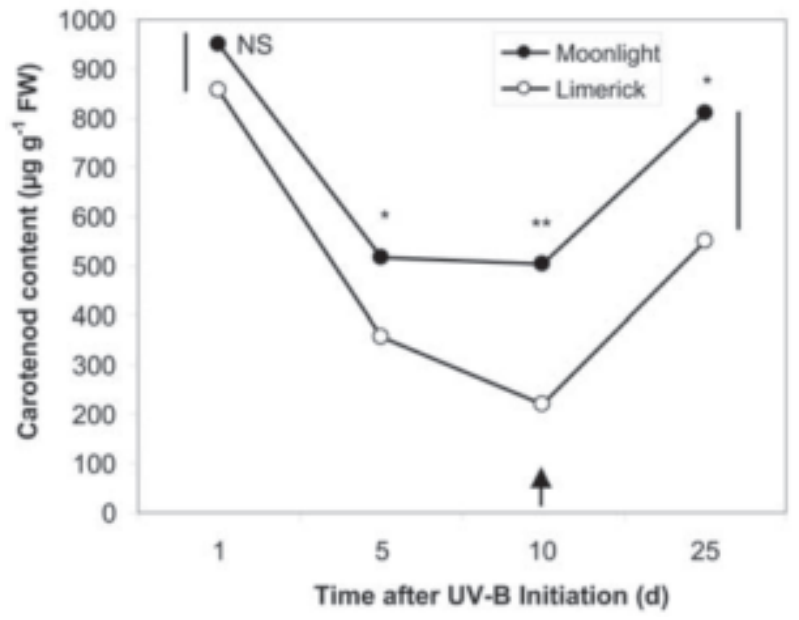

Fig. 4. Carotenoids content responses to artificial UV-B radiation stress (70 $\left.\mu \mathrm{mol} \cdot \mathrm{m}^{-2} \cdot \mathrm{s}^{-1}\right)$ in two kentucky bluegrass cultivars. The difference between the two cultivars was significant at $P=0.05(*), P=0.01(* *)$, or nonsignificant (NS) at a given day. The arrow indicates time of UV-B removal. Vertical bars represent LSD values $(P=0.05)$ values for 'Moonlight' (left) and 'Limerick' (right) over time of treatment.

stress initiation, carotenoid content was only 53\% ('Moonlight') and 26\% ('Limerick') of those measured at day 1. The carotenoids content in 'Moonlight' was 1.3-fold greater than that of 'Limerick,' when measured at day 10. At the end of the experiment, carotenoid content recovered to $85 \%$ of the original level in 'Moonlight', while recovery was only $64 \%$ in 'Limerick'.

Anthocyanin Content. UV-B did not impact anthocyanin content in either cultivar (Table 1). No anthocyanin difference between the cultivars was observed in this study. Anthocyanin showed a decline during the recovery period for both cultivars.

SUPEROXIDE DISMUTASE (SOD) ACTIVITY. The activity of SOD increased in 'Moonlight', but remained unchanged in 'Limerick' in response to UV-B stress (Fig. 5). When measured at day 10, SOD activity was $150 \%$ ('Moonlight') and 90\% ('Limerick') of the original level (day 1). At day 25, SOD activity was $84 \%$ ('Moonlight') and 71\% ('Limerick') of the original level. 'Moon-
Table 1. Anthocyanin content, and ascorbate peroxidase and peroxidase activity in two cultivars of kentucky bluegrass under UV-B stress.

\begin{tabular}{lccccc}
\hline & \multicolumn{5}{c}{ Time after UV-B initiation $(\mathrm{d})$} \\
\cline { 2 - 6 } Cultivar & 1 & 5 & 10 & 25 & LSD $_{0.05}$ \\
\hline Moonlight & $0.096 \mathrm{a}^{\mathrm{z}}$ & $0.081 \mathrm{a}$ & $0.105 \mathrm{a}$ & $0.029 \mathrm{a}$ & 0.032 \\
Limerick & $0.093 \mathrm{a}$ & $0.108 \mathrm{a}$ & $0.092 \mathrm{a}$ & $0.036 \mathrm{a}$ & 0.040 \\
\multicolumn{5}{c}{ Ascorbate peroxidase activity } & $($ unit/mg protein) \\
Moonlight & $0.23 \mathrm{a}$ & $0.18 \mathrm{a}$ & $0.22 \mathrm{a}$ & $0.12 \mathrm{a}$ & 0.109 \\
Limerick & $0.26 \mathrm{a}$ & $0.31 \mathrm{a}$ & $0.06 \mathrm{~b}$ & $0.15 \mathrm{a}$ & 0.141 \\
& \multicolumn{5}{c}{ Peroxidase activity (unit/mg protein) } \\
Moonlight & $0.39 \mathrm{a}$ & $0.68 \mathrm{a}$ & $0.78 \mathrm{a}$ & $0.29 \mathrm{~b}$ & 0.236 \\
Limerick & $0.37 \mathrm{a}$ & $0.67 \mathrm{a}$ & $0.82 \mathrm{a}$ & $0.34 \mathrm{a}$ & 0.417
\end{tabular}

zValues within each column followed by the same letter for each data set are not significantly different at $P \leq 0.05$.

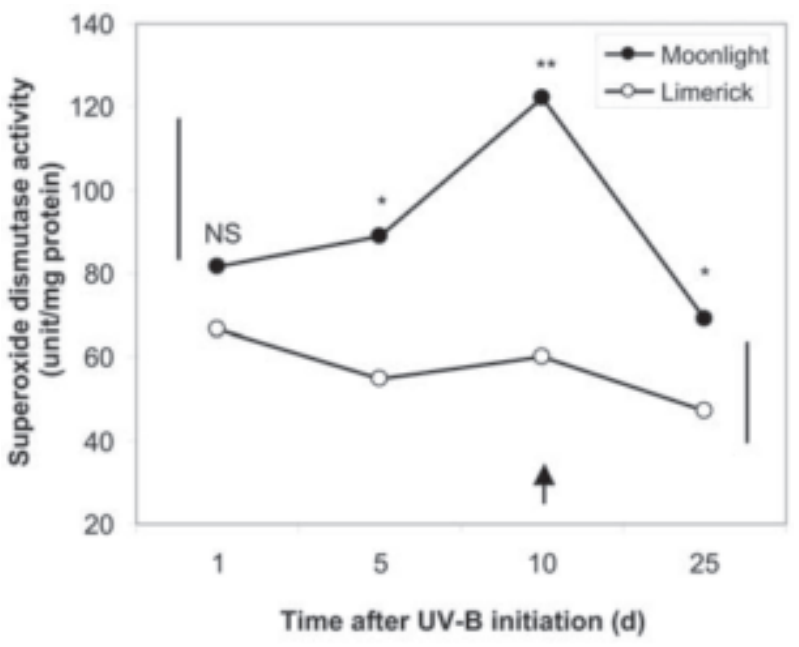

Fig. 5. Superoxide dismutase (SOD) activity responses to artificial UV-B radiation stress $\left(70 \mu \mathrm{mol} \cdot \mathrm{m}^{-2} \cdot \mathrm{s}^{-1}\right)$ in two kentucky bluegrass cultivars. The difference between the two cultivars was significant at $P=0.05(*), P=0.01(* *)$, or nonsignificant (Ns) at a given day. The arrow indicates time of UV-B removal. Vertical bars represent LSD values $(P=0.05)$ values for 'Moonlight' (left) and 'Limerick' (right) over time of treatment.

light' had greater SOD activity than 'Limerick' during UV-B stress and recovery periods.

Catalase (CAT) activity. The activity of CAT was decreased sharply in response to UV-B stress in both cultivars (Fig. 6). At $10 \mathrm{~d}$ of UV-B stress, CAT activity was $46 \%$ ('Moonlight') and $21 \%$ ('Limerick') of their original levels. At the end of the experiment, CAT activity had recovered to $65 \%$ ('Moonlight') and $40 \%$ ('Limerick') of the original levels.

Ascorbate PEROXIDASE (APX) AND PEROXIDASE (POD) ACTIVITIES. The activity of APX was not impacted by UV-B stress, except at $10 \mathrm{~d}$ of UV-B exposure when APX activity was $96 \%$ ('Moonlight') and 23\% ('Limerick') of the original level (day 1; Table 1). The activity of POD was increased in response to UV-B stress and decreased after removal of the stress (Table 1). No POD activity difference was found between two cultivars during UV-B stress; however, after $15 \mathrm{~d}$ of recovery, 'Limerick' had greater POD activity than 'Moonlight'. At the end of the experiment (day 25), POD activity was 74\% ('Moonlight') and 92\% ('Limerick') of the original level (day 1).

LIPID PEROXIDATION. UV-B caused an increase in lipid peroxidation in both cultivars (Fig. 7). The MDA content in 'Limerick' was 


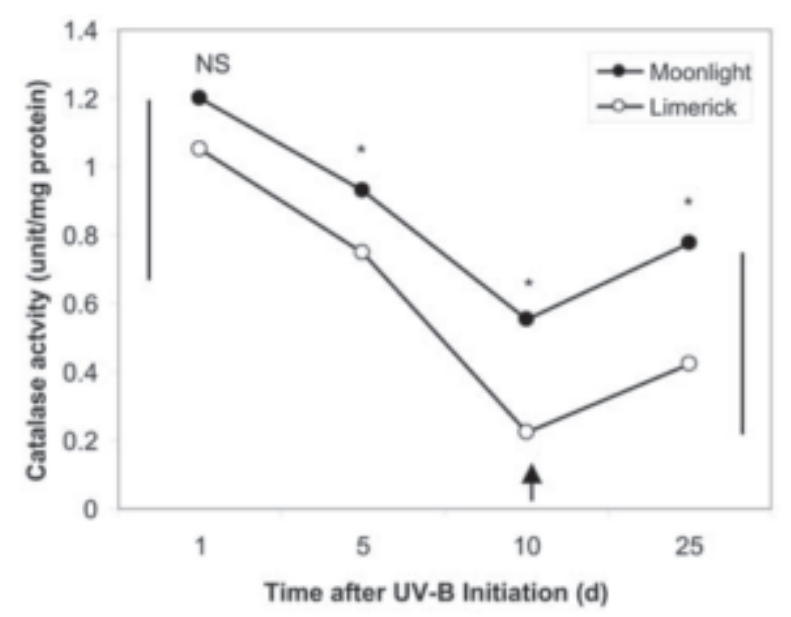

Fig. 6. Catalase (CAT) activity responses to artificial UV-B radiation stress (70 $\left.\mu \mathrm{mol} \cdot \mathrm{m}^{-2} \cdot \mathrm{s}^{-1}\right)$ in two kentucky bluegrass cultivars The difference between the two cultivars was significant at $P=0.05(*)$ or nonsignificant (NS) at a given day. The arrow indicates time of UV-B removal. Vertical bars represent LSD values $(P=0.05)$ values for 'Moonlight' (left) and 'Limerick' (right) over time of treatment.

$60 \%$ and $38 \%$ greater that those of 'Moonlight' when measured at day 5 and day 10 after UV-B initiation, respectively. When measured at day 10, MDA content was increased by $74 \%$ in 'Moonlight' and $121 \%$ in 'Limerick' relative to the original level. The MDA content was significantly decreased $15 \mathrm{~d}$ after UV-B stress was removed; however, the MDA content was similar to the original level in 'Moonlight', but still 29\% greater than the original level for 'Limerick' when measured at day 25.

Relationship OF QUALITY OR PEC WITH LEAF CONTENTS OF PIGMENTS AND ANTIOXIDANTS. Visual quality and PEc were positively correlated with contents of chlorophyll and carotenoids, activities of CAT, and SOD, and negatively correlated with MDA content based on the data from day 1 through day 25, except for SOD which was based on day 1 through day 10 (Table 2). A significant positive correlation was also found between turfgrass visual quality and PEc $(r=0.806 ; P \leq 0.01)$.

\section{Discussion}

The results of this study indicate that continuous UV-B irradiation $\left(70 \mu \mathrm{mol} \cdot \mathrm{m}^{-2} \cdot \mathrm{s}^{-1}\right)$ stress caused significant damage to visual quality, photochemical efficiency, and lipid stability in a relatively short period of time $(5 \mathrm{~d})$. The results are supported by previous studies (Ervin et al., 2004b; Lingakumar et al., 1999; Schmidt and Zhang, 2001; Strid and Porra, 1992). Ervin et al. (2004b) reported that UV-B stress damaged turf quality, PEc, and pigments of kentucky bluegrass. Lindakumar et al. (1999) found that exclusion of UV-B increased Fv/Fm, photosynthetic activity, and growth of Vigna unguiculata L. seedlings. It has been documented that UV-B causes oxidative stress and destroys pigments and depletes antioxidants, resulting in an increase of lipid peroxidation and quality decline (Ervin et al., 2004b; Mackerness, 2000).

The results of this study indicate the PEc declined rapidly in response to UV-B stress in either cultivar. However, PEc damage was less severe in the cultivar with the greatest levels of pigments and antioxidant enzymes. Photosystem II has been considered as one of the most susceptible sites to UV-B damage mainly because it is rich in polyunsaturated fatty acids (Lingakumar er al., 1999). Under UV-B stress, photosynthetic electron transport is inhibited and excess energy received by chlorophyll may be released as chlorophyll fluorescence or directed to $\mathrm{O}_{2}$, generating $\mathrm{ROS}$ in
Table 2. Correlation of turfgrass quality or canopy photochemical efficiency $[\mathrm{PEc}(\mathrm{Fv} / \mathrm{Fm})]$ with pigments, antioxidant enzymes, and lipid peroxidation in kentucky bluegrass subjected to UV-B stress. ${ }^{\mathrm{z}}$

\begin{tabular}{lcc}
\hline \multirow{2}{*}{ Parameter } & \multicolumn{2}{c}{ Correlation coefficient $(r)^{\mathrm{y}}$} \\
\cline { 2 - 3 } Chlorophyll $\mathrm{a}+\mathrm{b}$ & PEc (Fv/Fm) & Turfgrass quality \\
Anthocyanin & $0.739^{* *}$ & $0.794^{* *}$ \\
Carotenoids & $0.077^{\mathrm{NS}}$ & $-0.097^{\mathrm{NS}}$ \\
Catalase & $0.712^{* *}$ & $0.789^{* *}$ \\
Superoxide dismutase (SOD) & $0.470^{* *}$ & $0.632^{* *}$ \\
Ascorbate peroxidase & $0.667^{* * \mathrm{x}}$ & $0.769^{* *}$ \\
Peroxidase & $0.374^{*}$ & $0.295^{\mathrm{NS}}$ \\
PEc (Fv/Fm) & $-0.271^{\mathrm{NS}}$ & $-0.419^{\mathrm{NS}}$ \\
Lipid peroxidation & --- & $0.806^{* *}$ \\
\hline
\end{tabular}

${ }^{2}$ Turfgrass quality was rated on a visual scale of 1 to 9 , with 9 indicating the best quality.

y $r$ was based on data from day 1 through day 25 , except for superoxide dismutase (SOD).

${ }^{x} r$ between SOD and PEc was based on data of day 5 and day 10; $r$ between SOD and turfgrass quality was an average of $\mathrm{r}$ from day 5 and $\mathrm{r}$ from day 10 .

ss, ${ }^{*}, * *$ Nonsignificant or significant at $P=0.05$ or 0.01 , respectively.

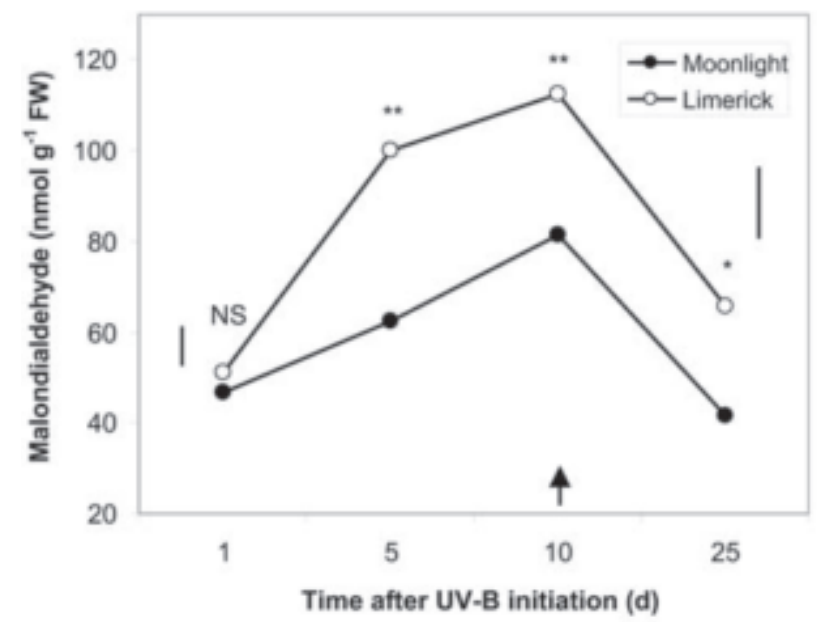

Fig. 7. Malondialdehyde (MDA) content responses to artificial UV-B radiation (70 $\left.\mu \mathrm{mol} \cdot \mathrm{m}^{-2 \cdot} \cdot \mathrm{s}^{-1}\right)$ stress in two kentucky bluegrass cultivars. The difference between the two cultivars was significant at $P=0.05(*), P=0.01(* *)$, or nonsignificant (Ns) at a given day. The arrow indicates time of UV-B removal. Vertical bars represent LSD values $(P=0.05)$ values for 'Moonlight' (left) and 'Limerick' (right) over time of treatment.

chloroplasts. Accumulation of ROS damages proteins, DNA, and membranes via lipid peroxidation, resulting in PEc decline (Smirnoff, 1995). 'Moonlight' had less lipid peroxidation (lower MDA) and greater PEc relative to 'Limerick'. This suggests that lipid peroxidation and PEc damage could be reduced by increasing antioxidant activity and pigment content.

Turfgrass PEc and quality were positively correlated with pigments such as carotenoids and negatively correlated with lipid peroxidation. 'Moonlight' had greater levels of carotenoids relative to 'Limerick' during UV-B stress and recovery periods. This is in agreement with the results from Ervin et al. (2004b), Lingakumar (1999), and Mackerness (2000). In the photosynthetic apparatus, carotenoids such as $\beta$-carotene quench both excited triplet state chlorophyll and singlet oxygen, preventing them from initiating lipid peroxidation (Perl-Treves and Perl, 2002). An excited carotene molecule can return to the ground state either by energy transfer to other pigments or by heat dissipation. Greater levels of carotenoids could reduce UV-B damage by suppressing toxic 
ROS and protecting chlorophyll. Using cultivars with greater contents of pigments such as carotenoids and chlorophyll could improve turfgrass resistance to UV-B stress.

It was also found that turfgrass $\mathrm{PEc}$ and visual quality were positively correlated with antioxidant enzymes such as CAT and SOD and negatively correlated with lipid peroxidation. It was noted that correlation of SOD activity with PEc and quality was statistically significant based on the data from day 5 and day 10 (Table 2 ), although nonsignificant when based on the data from day 1 through day 25. The differential response of SOD to UV-B stress in the two cultivars suggests that an increase of SOD activity may be an important defense mechanism of turfgrass against UV-B stress. 'Moonlight' had greater antioxidant enzyme activity and exhibited greater PEc and turfgrass quality only under UV-B stress. This is supported by the results of Ervin et al. (2004b), Langebartels et al. (2002), and Mackerness (2000). Antioxidant enzymes such as SOD and CAT can scavenge toxic ROS and prevent lipid peroxidation of the photosynthetic apparatus (Bornman et al., 1997; Rao et al., 1996; Teramura and Ziska, 1996). The results indicate that both selected pigments and antioxidant enzymes play important roles in UV-B resistance. This suggests that selecting and using cultivars with higher levels of selected pigments and antioxidant enzyme activity may reduce chlorophyll bleaching and improve turfgrass quality under UV-B stress (higher altitude, semi-arid, longer day light exposure) environments.

In sod production, one of the major concerns is rapid decline of newly transplanted sod. Previous studies have indicated that supraoptimal heating of sod while on the pallet predisposes leaf tissues to further damage when transplanted to a high UV-B field environment (Zhang at al., 2003). Use of darker green kentucky bluegrass cultivars in sod production may serve to dampen the damaging effects of UV-B and improve summer transplant success. As incident UV-B levels continue to rise due to stratospheric ozone depletion, turfgrass breeders, growers, and practitioners may want to consider selecting darker green cultivars with greater pigment content and antioxidant activity.

\section{Literature Cited}

Barker, N.R., S. Nogues, and D.J. Allen. 1997. Photosynthesis and photoinhibition, p. 95-112. In: P.J. Lumsden (ed.). Plant and UV-B: Responses to environmental changes. Cambridge Univ. Press, Cambridge, U.K.

Bornman, J.F., S. Reuber, Y.P. Cen, and G. Weissenbock. 1997. Ultraviolet radiation as a stress factor and the role of protective pigments, p. 157-170. In: P. Lumsden (ed.). Plant and UV-B: Responses to environmental damage. Cambridge Univ. Press, Cambridge, U.K.

Bowler, C., M. Van Montagu, and D. Inzé. 1992. Superoxide dismutase and stress tolerance. Annu. Rev. Plant Physiol. Plant Mol. Biol. 43:83-116.

Caldwell, M.M., R. Robberecht, and S.D. Flint. 1983. Internal filters: Prospects of UV-acclimation in higher plants. Phys. Planta 58:445-450.

Chance, B. and A.C. Maehly. 1955. Assay of catalase and peroxidases. Methods Enzymol. 2:764-775.

Costa, H., M. Susana, S.M. Gallego, and M.L. Tomaro. 2002. Effect of UV-B radiation on antioxidant defense system in sunflower cotyledons. Plant Sci. 162:939-945.

Ervin, E.H., X. Zhang, and J.H. Fike. 2004a. Ultraviolet B radiation damage on kentucky bluegrass, II: Hormone supplement effects. HortScience 39:1471-1474.

Ervin, E.H., X. Zhang, and J.H. Fike. 2004b. Ultraviolet B radiation damage on kentucky bluegrass, III: Cultivar effects. HortScience 39:1475-1477.

Giannopolitis, C.N. and S.K. Ries. 1977. Superoxide dismutase. I. Occurrence in higher plants. Plant Physiol. 59:309-314.

Heath, R.L. and L. Packer. 1968. Photoperoxidation in isolated chloroplasts. I. Kinetics and stoichiometry of fatty acid peroxidation. Arch. Biochem. Biophys. 125:189-198.

Heckman, N.L., G.L. Horst, R.E. Gaussoin, and K.W. Frank. 2001. Storage and handling characteristics of trinexapac-ethyl treated kentucky bluegrass sod. HortScience 36:1127-1130.

King, J.W., J.B. Beard, and P.E. Rieke. 1982. Factors affecting survival of kentucky bluegrass sod under simulated shipping conditions. J. Amer. Soc. Hort. Sci. 107:634-637.

Kondo, N. and K. Kawashima. 2000. Enhancement of the tolerance to oxidative stress in cucumber (Cucumis sativus L.) seedlings by UV-B irradiation: Possible involvement of phenolic compounds and antioxidant enzymes. J. Plant Res. 113:311-317.

Langebartels, C.L., M. Schraudner, W. Heller, D. Ernst, and H. Sandermann, Jr. 2002. Oxidative stress and defense reactions in plants exposed to air pollutants and UV-B radiation, p. 105-135. In: D. Inzé and M. Van Montagu (eds.). Oxidative stress in plants. Taylor and Francis, London.

Lichtenthaler. 1987. Chlorophylls and carotenoids: Pigments of photosynthetic biomembranes. Methods Enzymol. 148:350-382.

Lingakumar, K., P. Amudha, and G. Kulandaivelu. 1999. Exclusion of solar UV-B $(280-315 \mathrm{~nm})$ radiation on vegetative growth and photosynthetic activities in Vigna unguiculata L. Plant Sci. 148:97-103.

Mackerness, S.A.H. 2000. Plant responses to ultraviolet-B(UV-B: 280-320nm) stress: What are the key regulators? Plant Growth Regulat. 32:27-39.

Nakano, Y. and K. Asada. 1981. Hydrogen peroxide is scavenged by ascorbate-specific peroxidase in spinach chloroplasts. Plant Cell Physiol. 22:867-880.

Noorudeen, A.M. and G. Kulandaivelu. 1982. On the possible site of inhibition of photosynthetic electron transport by ultrabiolet-B (UV-B) radiation. Physiol. Planta 55:161-166.

Pallet, K.E. and A.J. Young. 1993. Carotenoids, p. 59-90. In: R.G. Alscher and J.L. Hess (eds.). Antioxidants in higher plants. CRC Press, Boca Raton, Fla.

Perez-Rodriguez, E., I. Gomez, U. Karsten, and F.L. Figueroa. 1998. Effects of UV radiation on photosynthesis and excretion of UV-absorbing compounds of Dasycladus vermicularis (Dasycladales, Chlorophyta) from southern Spain. Phycologia 37:379-387.

Perl-Treves, R. and A. Perl. 2002. Oxidative stress: An introduction, p. 1-32. In: D. Inzé and M. Van Montagu (eds.). Oxidative stress in plants. Taylor and Francis. London.

Rabino, I. and A.L. Mancinelli. 1986. Light, temperature, and anthocyanin production. Plant Physiol. 81:922-924.

Rao, M.V., G. Paliyath, and D.P. Ormrod. 1996. Ultraviolet-B and ozoneinduced biochemical changes in antioxidant enzymes of Arabidopsis thaliana. Plant Physiol. 110:125-136.

SAS Institute, Inc. 2001. SAS system for Windows. Version 8e. SAS Inst., Cary, N.C.

Schmidt, R.E. and X. Zhang. 2001. Alleviation of photochemical activity decline of turfgrasses exposed to soil moisture stress or UV radiation. Intl. Turfgrass Res. J. 9:340-346.

Smirnoff, N. 1995. Antioxidant systems and plant response to the environment, p. 217-244. In: N. Smirnoff (ed.). Environment and plant metabolism: Flexibility and acclimation. BIOS Sci. Publ., Oxford, U.K.

Smith, P.K. 1985. Measurement of protein using bicinchoninic acid. Anal. Biochem. 150:76-85.

Strid, A. and R.J. Porra. 1992. Alterations in pigment concentration in leaves of Pisum sativum after exposure to supplementary UV-B. Plant Cell Physiol. 33:1015-1023.

Takeuchi, Y., R. Fukumoto, H. Kasahara, T. Sakaki, and K. Mitsutoshi. 1995. Peroxidation of lipids and growth inhibition induced by UV-B irradiation. Plant Cell Environ. 14:566-570.

Teramura, A.H., J.H. Sullivan, and L.H. Ziska. 1990. Interaction of elevated ultraviolet $\mathrm{B}$ radiation and $\mathrm{CO}_{2}$ on productivity and photosynthetic characteristics in wheat, rice, and soybean. Plant Physiol. 94:470-475.

Teramura, A.H. and L.H. Ziska. 1996. Ultraviolet-B radiation and photosynthesis, p. 435-450. In: N.R. Baker(ed.). Photosynthesis and the environment. Kluwer Academic Publ., Dordrecht, The Netherlands.

Tevini, M. and A.H. Teramura. 1989. UV-B effects on terrestrial plants. Photochem. Photobiol. 50:479-487.

Zhang, X., E. Ervin, and R.E. Schmidt. 2003. Plant growth regulators can enhance the recovery of kentucky bluegrass sod from heat injury. Crop Sci. 43:952-956.

Zhang, X. and R.E. Schmidt. 2000. Application of trinexapac-ethyl and propiconazole enhances superoxide dismutase and photochemical activity in creeping bentgrass (Agrostis stoloniferous var. palustris). J. Amer. Soc. Hort. Sci. 125:47-51. 